\title{
PENGARUH PEMUPUKAN N, P DAN K TERHADAP PRODUKTIVITAS DAN MUTU MINYAK Mentha arvensis
}

\author{
Effect of N, $P$ and $K$ fertilizer to the yield and quality of Mentha arvensis oil \\ Octivia Trisilawati*, Ekwasita Rini Pribadi, Molide Rizal, Sintha Suhirman \\ Balai Penelitian Tanaman Rempah dan Obat \\ Jl. Tentara Pelajar No.3, Cimanggu, Bogor-Jawa Barat 16111 \\ *Email korespondensi: trisilawati03@gmail.com
}

Diterima 6 September 2020/Disetujui 21 Oktober 2020

\begin{abstract}
ABSTRAK
Mentha arvensis merupakan tanaman herba tahunan penghasil minyak menthol yang digunakan dalam industri farmasi dan makanan. Sebagai sumber menthol dan dimentolized oil, tanaman ini mempunyai peluang menguntungkan untuk dibudidayakan sesuai dengan kondisi agroklimat Indonesia. Penelitian dilakukan untuk mengetahui respon dua nomor harapan Mentha arvensis L. terhadap pemupukan $\mathrm{N}, \mathrm{P}$, dan $\mathrm{K}$ yang ditanam di kebun percobaan Cicurug (jenis tanah latosol, ketinggian $550 \mathrm{~m}$ dpl.). Penelitian dilaksanakan selama 4 bulan, menggunakan rancangan acak kelompok faktorial, dengan 3 ulangan dan 2 faktor. Faktor pertama adalah dua nomor harapan $M$. arvensis (Mear 0010 dan Mear 0012), faktor kedua adalah pupuk N, P dan K: a). kontrol, b). $\left.\left.69 \mathrm{~kg} \mathrm{~N}+54 \mathrm{~kg} \mathrm{P}_{2} \mathrm{O}_{5}+94,5 \mathrm{~kg} \mathrm{~K} 2 \mathrm{O}, \mathrm{c}\right) .69 \mathrm{~kg} \mathrm{~N}+72 \mathrm{~kg} \mathrm{P}_{2} \mathrm{O}_{5}+94,5 \mathrm{~kg} \mathrm{~K} 2 \mathrm{O}, \mathrm{d}\right)$. $\left.\left.69 \mathrm{~kg} \mathrm{~N}+90 \mathrm{~kg} \mathrm{P}_{2} \mathrm{O}_{5}+94,5 \mathrm{~kg} \mathrm{~K}_{2} \mathrm{O}, \mathrm{e}\right) .92 \mathrm{~kg} \mathrm{~N}+90 \mathrm{~kg} \mathrm{P}_{2} \mathrm{O}_{5}+126 \mathrm{~kg} \mathrm{~K} 2 \mathrm{O}, \mathrm{f}\right) .92 \mathrm{~kg} \mathrm{~N}+72 \mathrm{~kg}$ $\left.\mathrm{P}_{2} \mathrm{O}_{5}+126 \mathrm{~kg} \mathrm{~K} 2 \mathrm{O}, \mathrm{g}\right) .138 \mathrm{~kg} \mathrm{~N}+90 \mathrm{~kg} \mathrm{P}_{2} \mathrm{O}_{5}+126 \mathrm{~kg} \mathrm{~K}_{2} \mathrm{O}$ per ha. Peubah yang diamati adalah pertumbuhan tanaman yang meliputi tinggi, jumlah daun dan jumlah cabang serta produksi yang meliputi bobot segar dan kering terna, kadar minyak, kadar menthol bebas dan kadar menthol total. Hasil penelitian menunjukkan bahwa pemupukan berpengaruh nyata terhadap bobot kering terna, produksi minyak dan kadar menthol $M$. arvensis. Pemupukan $92 \mathrm{~kg} \mathrm{~N}+72 \mathrm{~kg} \mathrm{P}_{2} \mathrm{O}_{5}+126 \mathrm{~kg}$ $\mathrm{K}_{2} \mathrm{O} /$ ha pada tanaman $M$. arvensis, menghasilkan bobot terna, kadar minyak, kadar menthol total dan hasil minyak mentha terbaik. Produksi minyak dan menthol yang dihasilkan masing-masing sebesar 41 dan $25 \mathrm{~kg} /$ ha per panen. Jumlah hara $\mathrm{N}, \mathrm{P}, \mathrm{K}$ yang terangkut berturut-turut $\mathrm{N}>\mathrm{K}>\mathrm{P}$.
\end{abstract}

Kata kunci: Mentha arvensis L., pupuk, nomor harapan, produksi

\section{ABSTRACT}

Mentha arvensis is an annual herbaceous plant that produces cornmint oil used for pharmaceutical and food industries. As a source of menthol and dimentolized oil, M. arvensis has a profitable opportunity to be cultivated in Indonesian agroclimate. The research was conducted to obtain the optimal dosages of N, $P$ and $K$ fertilizers, for increasing the yield and oil quality of $M$. arvensis, planted in Cicurug Research garden (latosol soil, $550 \mathrm{~m}$ asl.), by using randomized block design, with two factors, arranged factorially, with 3 replications. First factor was $M$. arvensis promising number (Mear 0010 and Mear 0012), and fsecond factor was NPK fertilizer, included: a). control, b). $\left.69 \mathrm{~kg} \mathrm{~N}+54 \mathrm{~kg} \mathrm{P}_{2} \mathrm{O}_{5}+94,5 \mathrm{~kg} \mathrm{~K} 2 \mathrm{O}, \mathrm{c}\right) .69 \mathrm{~kg} \mathrm{~N}+72 \mathrm{~kg} \mathrm{P}_{2} \mathrm{O}_{5}+94,5$ $\left.\mathrm{kg} \mathrm{K} \mathrm{K}_{2} \mathrm{O}, \mathrm{d}\right) .69 \mathrm{~kg} \mathrm{~N}+90 \mathrm{~kg} \mathrm{P}_{2} \mathrm{O}_{5}+94,5 \mathrm{~kg} \mathrm{~K} \mathrm{~K}_{2} \mathrm{O}$, e). $\left.92 \mathrm{~kg} \mathrm{~N}+90 \mathrm{~kg} \mathrm{P}_{2} \mathrm{O}_{5}+126 \mathrm{~kg} \mathrm{~K} 2 \mathrm{O}, \mathrm{f}\right) .92$ 
$\mathrm{kg} \mathrm{N}+72 \mathrm{~kg} \mathrm{P}_{2} \mathrm{O}_{5}+126 \mathrm{~kg} \mathrm{~K}{ }_{2} \mathrm{O}$, and g). $138 \mathrm{~kg} \mathrm{~N}+90 \mathrm{~kg} \mathrm{P}_{2} \mathrm{O}_{5}+126 \mathrm{~kg} \mathrm{~K} \mathrm{O}_{2}$ per ha. Variables observed were plant height, number of leaf and branch, biomass weight, oil content, free menthol content, and total menthol content. The results showed that application of $92 \mathrm{~kg} \mathrm{~N}+72 \mathrm{~kg} \mathrm{P}_{2} \mathrm{O}_{5}$ $+126 \mathrm{~kg} \mathrm{~K} \mathrm{~K}_{2} \mathrm{O} / \mathrm{ha}$ equivalent to $200 \mathrm{~kg}$ Urea $+200 \mathrm{~kg} \mathrm{SP}-36+200 \mathrm{~kg} \mathrm{KCl} / \mathrm{ha}$ to $\mathrm{M}$. arvensis, resulted better herb biomass, oil content, total menthol content and oil yield at first harvest compared with other fertilizer treatments. At first harvest, oil and menthol yield were 41 and 25 $\mathrm{kg} / \mathrm{ha}$. The uptake of $N, P, K$ nutrients were $N>K>P$, respectively.

Keywords : Mentha arvensis L., fertilizers, production, total menthol

\section{PENDAHULUAN}

Mentha arvensis $L$, sebagai penghasil minyak cornmint atau minyak mentha Jepang (Japanese mint) merupakan spesies penting dari genus Mentha. Kandungan minyak atsirinya kaya akan senyawa monoterpen, seskuiterpen dan senyawa-senyawa yang mudah menguap dan memberikan rasa mint yang khas seperti mentol, menthone, carvacol, pulgone dan isomenthone. Tanaman ini mempunyai nilai ekspor yang tinggi dan telah banyak dikembangkan di beberapa negara seperti India, Argentina, Australia, Brazil, dan Afrika Selatan (Munsi 1992; Tiwari 2016).

Di Indonesia, mentol banyak digunakan pada industri makanan seperti coklat dan kembang gula (confectionery), minuman ringan, farmasi, rokok kretek, jamu, sabun dan bahan pembersih keperluan rumah tangga termasuk pasta gigi, kosmetik perekat atau lem (BPSb 2007). Menurut Pribadi (2010) impor mentol untuk industri di Indonesia 76,10 ton/tahun, sehingga substitusi impor dengan memproduksi minyak menthol di dalam negeri merupakan langkah strategis.

Peluang pengembangan $M$. arvensis di Indonesia masih sangat tinggi, karena tidak memerlukan panjang hari tertentu untuk berbunga, seperti umumnya tanaman introduksi dari daerah sub tropis. M. arvensis dapat tumbuh dan berproduksi optimal di dataran rendah sampai medium $(100-700$ $\mathrm{m}$ dari atas permukaan laut (dpl)), curah hujan 2000 - $4000 \mathrm{~mm} / \mathrm{tahun}$. Tipe iklim yang cocok A, B1, dan B2 (Oldeman), dengan bulan basah $>7$ bulan dan bulan kering $<3$ bulan. Suhu $20-30{ }^{\circ} \mathrm{C}$, kelembaban $70-80 \%$, dan intensitas cahaya penuh. Jenis tanah yang dikehendaki adalah tanah latosol dan andosol, tanah dengan tekstur lempung debu berpasir, liat berpasir, subur dan kaya bahan organik, berdrainase baik dengan $\mathrm{pH}$ tanah 5,5 - 7,0 (Ditjenbun 2008). Kebutuhan hara tanaman antara lain dipengaruhi oleh varietas dan kondisi agroklimat.

Budidaya mentha sampai saat ini masih menghadapi kendala, yaitu rendahnya produksi dan mutu minyak yang rata-rata hanya mencapai $11-52 \mathrm{~kg} / \mathrm{ha}$ pada panen I dengan kadar menthol bebas bervariasi $(48,6 \%$ - 53,1\%), serta rendemen minyak hanya $1,6 \%-2,2 \%$. Perbaikan teknik budidaya melalui pemupukan diharapkan dapat meningkatkan produksi minyak dan menthol.

Hasil penelitian menunjukkan aplikasi $100 \mathrm{~kg}$ Urea + $200 \mathrm{~kg}$ TSP pada tanah Andosol Lembang, menghasilkan minyak Mentha arvensis var. Ryokubi sebesar 61,57 1/ha (panen pertama), sedangkan $100 \mathrm{~kg}$ Urea $+300 \mathrm{~kg}$ TSP sebesar $63,721 /$ ha, dengan kadar menthol berkisar 
41,7 - 49,4\% (Trisilawati dan Hobir 1991). Aplikasi pemupukan $100 \mathrm{~kg} \mathrm{~N}$ dan $60 \mathrm{~kg}$ P/ha pada pertanaman Mentha arvensis menghasilkan bobot segar dan kering biomas, dan kandungan minyak yang nyata lebih tinggi dibandingkan kombinasi pupuk $\mathrm{N}$ dan $\mathrm{P}$ lainnya. Aplikasi $100 \mathrm{~kg} \mathrm{P}_{2} \mathrm{O}_{5} / \mathrm{ha}$ pada $M$. arvensis Mear 0012 di polybag di rumah kaca Cimanggu, Bogor, menghasilkan bobot segar dan kering terna serta rerata kadar menthol total tertinggi $(56,20 \%)$ pada panen pertama, sedangkan pemberian $100 \mathrm{~kg}$ $\mathrm{N}+300 \mathrm{~kg} \mathrm{P}_{2} \mathrm{O}_{5} / \mathrm{ha}$ menghasilkan rerata kadar minyak tertinggi (2,15\%). Pada $M$. arvensis Mear 0013, kadar minyak tertinggi dihasilkan dari perlakuan $100 \mathrm{~kg} \mathrm{P}_{2} \mathrm{O}_{5} /$ ha dan kadar menthol total tertinggi dari $100 \mathrm{~kg} \mathrm{~N}$ $+300 \mathrm{~kg} \mathrm{P}_{2} \mathrm{O}_{5} /$ ha (Trisilawati, 2012).

Tujuan penelitian ini adalah untuk mendapatkan dosis $\mathrm{N}, \mathrm{P}$ dan $\mathrm{K}$ yang dapat meningkatkan produktivitas dan mutu minyak mentha dan total menthol pada kondisi agroklimat lahan kebun percobaan Cicurug, Sukabumi (550 m dpl.).

\section{BAHAN DAN METODE}

Penelitian pemupukan $M$. arvensis dilaksanakan di kebun percobaan Cicurug (jenis tanah latosol pada ketinggian $550 \mathrm{~m}$ dpl.), selama 6 bulan, dengan kondisi iklim: 15 jumlah hari hujan dan 348,6 ml curah hujan per tahun. Nomor harapan $M$. arvensis yang digunakan dua, yaitu Mear 0010 dan Mear 0012. Penyiapan benih dilakukan selama 1 bulan di rumah kaca pada polybag $(10 \times 15 \mathrm{~cm})$ dengan media tanah dan pupuk kandang (2:1). Pemberian 1-2 ton kaptan/ha pada bedengan dilakukan 2 minggu sebelum tanam, dan pupuk dasar $20 \mathrm{t}$ pupuk kandang/ha ( $\pm 0,5 \mathrm{~kg} / \mathrm{tanaman})$ diberikan satu minggu sebelum tanam. Ukuran plot 12 $\mathrm{m}^{2}$, jarak tanam $60 \mathrm{~cm} \mathrm{x} 40 \mathrm{~cm}$, pada luasan $\pm 750 \mathrm{~m}^{2}$. Pemupukan dilakukan pada 2 minggu setelah tanam ( $1 / 2$ dosis Urea, total SP-36 dan $\mathrm{KCl}$ ), dan 2 bulan setelah tanam
(1/2 dosis Urea). Hasil analisis kondisi kesuburan lahan di KP. Cicurug menunjukkan: $\mathrm{pH}$ tanah masam $(4,6)$, kandungan $\mathrm{C}$ organik $(1,7 \%) \mathrm{N}$ total tanah $(0,17 \%)$, dan $\mathrm{P}$ tersedia $(13,71 \mathrm{ppm})$ tergolong rendah, tingkat dekomposisi bahan organik rendah (C/N 10), basa-basa dapat ditukar seperti $\mathrm{Ca}(4,12 \mathrm{me} / 100 \mathrm{~g})$ dan $\mathrm{Na}$ $(0,24 \mathrm{me} / 100 \mathrm{~g})$ tergolong rendah, sedangkan $\mathrm{K}(0,48 \mathrm{me} / 100 \mathrm{~g})$ dan $\mathrm{Mg}(1,12 \mathrm{me} / 100 \mathrm{~g})$ sedang, Kapasitas tukar kation (17,90 me/100 g) sedang dan Kejenuhan basa (35,53\%) rendah (Laboratorium 2009).

Rancangan yang digunakan adalah Acak Kelompok, disusun faktorialFaktor pertama adalah nomor harapan Mentha arvensis (Mear 0010 dan Mear 0012), sedangkan faktor kedua adalah dosis pemupukan $\mathrm{N}, \mathrm{P}$ dan $\mathrm{K}$, yang terdiri atas a). kontrol, b). $69 \mathrm{~kg} \mathrm{~N}+54 \mathrm{~kg} \mathrm{P} \mathrm{O}_{5}+94,5 \mathrm{~kg}$ $\left.\mathrm{K}_{2} \mathrm{O}, \mathrm{c}\right) .69 \mathrm{~kg} \mathrm{~N}+72 \mathrm{~kg} \mathrm{P}_{2} \mathrm{O}_{5}+94,5 \mathrm{~kg} \mathrm{~K}_{2} \mathrm{O}$, d). $69 \mathrm{~kg} \mathrm{~N}+90 \mathrm{~kg} \mathrm{P}_{2} \mathrm{O}_{5}+94,5 \mathrm{~kg} \mathrm{~K}_{2} \mathrm{O}$, e). $\left.92 \mathrm{~kg} \mathrm{~N}+90 \mathrm{~kg} \mathrm{P}_{2} \mathrm{O}_{5}+126 \mathrm{~kg} \mathrm{~K} 2 \mathrm{O}, \mathrm{f}\right) .92 \mathrm{~kg}$ $\left.\mathrm{N}+72 \mathrm{~kg} \mathrm{P}_{2} \mathrm{O}_{5}+126 \mathrm{~kg} \mathrm{~K} 2 \mathrm{O}, \mathrm{g}\right) .138 \mathrm{~kg} \mathrm{~N}$ $+90 \mathrm{~kg} \mathrm{P}_{2} \mathrm{O}_{5}+126 \mathrm{~kg} \mathrm{~K} 2 \mathrm{O}$ per ha. Setiap kombinai perlakuan diulang tiga kali, sehingga terdapat 42 satuan percobaan. Masing-masing satuan percobaan terdiri atas 50 tanaman.

Panen terna dilakukan pada umur 3 bulan setelah tanam (saat 50-75\% tanaman sudah berbunga), dengan memangkas tanaman $\pm 20 \mathrm{~cm}$ dari permukaan tanah. Bunga merupakan indikator waktu panen mentha terbaik, karena kadar minyak dan menthol mencapai maksimum pada masa pembungaan penuh (Hadipoentyanti 1996). Terna dikeringkan sampai kadar air sekitar 30-35\%, kemudian disuling dengan cara uap langsung (steam distillation) selama 2 jam dengan tekanan 1 atmosfer diketel. Minyak hasil penyulingan dipisahkan dari airnya dan dikeringkan dengan $\mathrm{Na}_{2} \mathrm{SO}_{4}$ anhidrat, kemudian disaring. Kadar menthol dianalisis dengan GC (Kromatografi Gas) dan isolasi 
menthol dengan cara pendinginan dan penyabunan (Ma'mun dan Shinta 2009).

Pengamatan peubah pertumbuhan dilakukan setiap satu bulan, sedangkan produksi terna, kadar minyak, mutu minyak, kadar mentol bebas, dan serapan hara $\mathrm{N}, \mathrm{P}, \mathrm{K}$ dilakukan

\section{HASIL DAN PEMBAHASAN}

\section{Pertumbuhan Tanaman}

Hasil analisis pertumbuhan vegetatif tanaman yang meliputi tinggi, jumlah daun, setelah panen pertama. Data dianalisis dengan ANOVA dan jika menunjukan pengaruh nyata, maka dilanjutkan dengan uji jarak berganda Duncan's Multiple Range Test.

jumlah cabang primer dan jumlah cabang sekunder menunjukkan bahwa perlakuan no harapan dan dosis pemupukan NPK tidak berpengaruh nyata (Tabel 1).

Tabel 1 Pertumbuhan vegetatif M. arvensis pada berbagai dosis pupuk N, P dan K

\begin{tabular}{lcccc}
\hline Perlakuan & $\begin{array}{c}\text { Tinggi } \\
\text { tanaman } \\
(\mathrm{cm})\end{array}$ & $\begin{array}{c}\text { Jumlah } \\
\text { daun }\end{array}$ & $\begin{array}{c}\text { Jumlah } \\
\text { cabang } \\
\text { primer }\end{array}$ & $\begin{array}{c}\text { Jumlah cabang } \\
\text { sekunder }\end{array}$ \\
No Harapan & & & & \\
\hline Mear 0010 & 30,45 & 369,44 & 16,60 & 42,31 \\
Mear 0012 & 53,51 & 673,45 & 27,75 & 71,13 \\
\hline Dosis NPK & & & & \\
\hline Kontrol & 52,34 & 701,27 & 28,33 & 74,58 \\
69 kg N + 54 kg P $\mathrm{O}_{5}+94,5 \mathrm{~kg} \mathrm{~K}_{2} \mathrm{O}$ & 51,66 & 531,29 & 29,44 & 68,90 \\
$69 \mathrm{~kg} \mathrm{~N}+72 \mathrm{~kg} \mathrm{P}_{2} \mathrm{O}_{5}+94,5 \mathrm{~kg} \mathrm{~K}_{2} \mathrm{O}$ & 28,15 & 352,05 & 13,30 & 35,72 \\
$69 \mathrm{~kg} \mathrm{~N}+90 \mathrm{~kg} \mathrm{P}_{2} \mathrm{O}_{5}+94,5 \mathrm{~kg} \mathrm{~K}_{2} \mathrm{O}$ & 27,37 & 387,87 & 14,18 & 36,74 \\
$92 \mathrm{~kg} \mathrm{~N}+90 \mathrm{~kg} \mathrm{P} \mathrm{O}_{5}+126 \mathrm{~kg} \mathrm{~K} \mathrm{O}_{2} \mathrm{O}$ & 26,79 & 341,50 & 13,55 & 34,46 \\
$92 \mathrm{~kg} \mathrm{~N}+72 \mathrm{~kg} \mathrm{P}_{2} \mathrm{O}_{5}+126 \mathrm{~kg} \mathrm{~K} \mathrm{O}_{2} \mathrm{O}$ & 54,07 & 713,49 & 26,90 & 72,58 \\
$138 \mathrm{~kg} \mathrm{~N}+90 \mathrm{~kg} \mathrm{P}_{2} \mathrm{O}_{5}+126 \mathrm{~kg} \mathrm{~K}_{2} \mathrm{O}$ & 53,46 & 622,65 & 29,51 & 74,09 \\
\hline
\end{tabular}

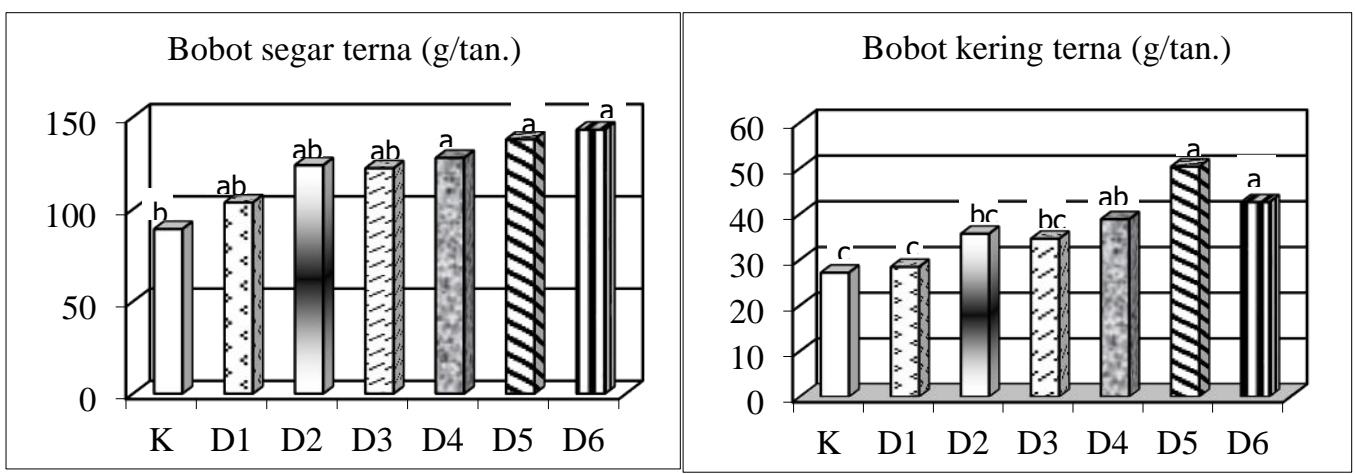

Keterangan: $\mathrm{K}=$ kontrol, $\mathrm{D} 1=69 \mathrm{~kg} \mathrm{~N}+54 \mathrm{~kg} \mathrm{P}_{2} \mathrm{O}_{5}+94,5 \mathrm{~kg} \mathrm{~K} 2 \mathrm{O}, \mathrm{D} 2=69 \mathrm{~kg} \mathrm{~N}+72 \mathrm{~kg} \mathrm{P}_{2} \mathrm{O}_{5}+94,5 \mathrm{~kg} \mathrm{~K} 2 \mathrm{O}, \mathrm{D} 3$ $=69 \mathrm{~kg} \mathrm{~N}+90 \mathrm{~kg} \mathrm{P}_{2} \mathrm{O}_{5}+94,5 \mathrm{~kg} \mathrm{~K}_{2} \mathrm{O}, \mathrm{D} 4=92 \mathrm{~kg} \mathrm{~N}+90 \mathrm{~kg} \mathrm{P}_{2} \mathrm{O}_{5}+126 \mathrm{~kg} \mathrm{~K}_{2} \mathrm{O}, \mathrm{D} 5=92 \mathrm{~kg} \mathrm{~N}+72$ $\mathrm{kg} \mathrm{P}_{2} \mathrm{O}_{5}+126 \mathrm{~kg} \mathrm{~K}_{2} \mathrm{O}, \mathrm{D} 6=138 \mathrm{~kg} \mathrm{~N}+90 \mathrm{~kg}_{2} \mathrm{O}_{5}+126 \mathrm{~kg} \mathrm{~K} \mathrm{O}$

Gambar 1 Bobot segar dan kering terna M. Arvensis pada berbagai dosis pupuk N, P dan K 
Hal tersebut sejalan dengan penelitian uji adaptabilitas $M$. arvensis di KP. Cicurug, yang mendapatkan bahwa pertumbuhan tiga nomor harapan yaitu Mear 0010, Mear 0011 dan Mear 0012 tidak berbeda nyata (Endang et al. 2009).

\section{Produksi tanaman}

Nomor harapan tidak berpengaruh nyata terhadap produksi $M$. arvensis, sedangkan pemupukan berpengaruh nyata terhadap bobot segar dan kering terna, serta kadar minyak dan kadar menthol (Gambar 1 dan Tabel 2). Aplikasi $138 \mathrm{~kg} \mathrm{~N}+90 \mathrm{~kg} \mathrm{P}_{2} \mathrm{O}_{5}+$ $126 \mathrm{~kg} \mathrm{~K}_{2} \mathrm{O} / \mathrm{ha}$ menghasilkan bobot segar terna tertinggi yaitu $143 \mathrm{~g} / \mathrm{tan}$. atau sekitar 5,7 t terna segar/ha, diikuti oleh perlakuan $92 \mathrm{~kg} \mathrm{~N}+72 \mathrm{~kg} \mathrm{P}_{2} \mathrm{O}_{5}+126 \mathrm{~kg} \mathrm{~K} \mathrm{~K}_{2} \mathrm{O}, 138$ $\mathrm{g} / \mathrm{tan}$. atau sekitar 5,5 t/ha. Bobot kering terna tertinggi dihasilkan dari perlakuan 92

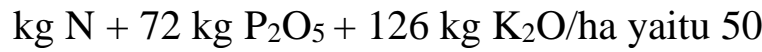
$\mathrm{g} / \mathrm{tan}$. atau sekitar $2 \mathrm{t}$ terna/ha, diikuti oleh perlakuan $138 \mathrm{~kg} \mathrm{~N}+90 \mathrm{~kg} \mathrm{P}_{2} \mathrm{O}_{5}+126 \mathrm{~kg}$ $\mathrm{K}_{2} \mathrm{O}, 43 \mathrm{~g} / \mathrm{tan}$. atau sekitar 1,6 t terna/ha dan

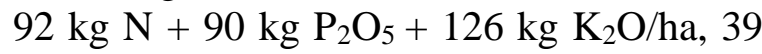
$\mathrm{g} / \mathrm{tan}$. atau sekitar 1,4 t terna/ha. Hasil ini lebih tinggi dibandingkan dengan hasil penelitian Shormin et al. (2009), M. arvensis yang ditanam dengan kondisi agroklimat di Pakistan dan dipupuk dengan $240 \mathrm{~kg} \mathrm{~N} / \mathrm{ha}$ menghasilkan pertumbuhan dan bobot terna segar tertinggi (103,54 g terna/pot) ( 09).

Hasil penelitian selama 2 tahun di India menunjukkan bahwa aplikasi pupuk $\mathrm{N}$ dan $\mathrm{P}$ nyata meningkatkan bobot segar dan kering terna, serta kandungan minyak atsiri Japanese mint. Pemupukan N lebih berpengaruh terhadap produksi Mentha dibandingkan pupuk P. Pemupukan $200 \mathrm{~kg}$ $\mathrm{N}, 80 \mathrm{~kg} \mathrm{P}, 80 \mathrm{~kg} \mathrm{~K}$ menghasilkan bobot segar dan kering terna tertinggi yaitu sekitar 26 sampai 34 t/ha dan 6,4 sampai 8,3 t/ha. Selain itu, peningkatan dosis pupuk NPK akan berpengaruh secara signifikan terhadap produksi minyak mentha dari beberapa kultivar $M$. arvensis. Pemupukan NPK dengan dosis $200 \mathrm{~kg} \mathrm{~N}, 80 \mathrm{~kg}$ P $80 \mathrm{~kg} \mathrm{~K}$ dan $100 \mathrm{~kg} \mathrm{~N}, 60 \mathrm{~kg} P 60 \mathrm{~kg} \mathrm{~K}$ menghasilkan produksi minyak Mentha yang tinggi yaitu 266 sampai 354 liter/ha dibandingkan dosis pemupukan NPK yang lebih rendah (Anwar et al. 2010).

Pada M. arvensis Mear 0010, mempunyai kadar minyak yang relatif tinggi sebesar $2,57 \%$ pada perlakuan $138 \mathrm{~kg} \mathrm{~N}+90$ $\mathrm{kg} \mathrm{P}_{2} \mathrm{O}_{5}+126 \mathrm{~kg} \mathrm{~K} \mathrm{~K}_{2} \mathrm{O}$, diikuti perlakuan 69 $\mathrm{kg} \mathrm{N}+90 \mathrm{~kg} \mathrm{P}_{2} \mathrm{O}_{5}+94,5 \mathrm{~kg} \mathrm{~K} 2 \mathrm{O}$ sebesar 2,4 $\%$, sedangkan menthol total yang relatif tinggi didapat pada perlakuan $69 \mathrm{~kg} \mathrm{~N}+72$ $\mathrm{kg} \mathrm{P}_{2} \mathrm{O}_{5}+94,5 \mathrm{~kg} \mathrm{~K}_{2} \mathrm{O}$ sebesar 65,54\% dan

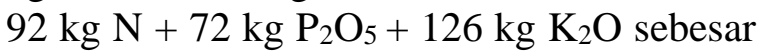
$64 \%$. Bila diperhitungkan dengan bobot kering terna dan kadar minyak yang diperoleh, maka untuk sekali panen, perlakuan $138 \mathrm{~kg} \mathrm{~N}+90 \mathrm{~kg} \mathrm{P}_{2} \mathrm{O}_{5}+126 \mathrm{~kg}$ $\mathrm{K}_{2} \mathrm{O}$ dapat menghasilkan $\pm 54 \mathrm{~kg}$ minyak, perlakuan $92 \mathrm{~kg} \mathrm{~N}+72 \mathrm{~kg} \mathrm{P}_{2} \mathrm{O}_{5}+126 \mathrm{~kg}$ $\mathrm{K}_{2} \mathrm{O}$ menghasilkan $\pm 52 \mathrm{~kg}$ minyak. Kadar menthol total memenuhi harapan (> 50\%), yaitu berkisar 57,03 - 65,54 \% . Pada umumnya Mentha sp. mengandung 40-85\% mentol sebagai senyawa utama. Mentha piperita (American peppermint) mengandung 50-55\% mentol dan Mentha arvensis memiliki kandungan mentol lebih tinggi yaitu 80-85\% (Ozguven dan Kirici 1999). Standar mutu dementholized oil menurut Standar Amerika (EOA), total menthol berkisar 40\%-60\%, sedangkan karakteristik mutu minyak cornmint menurut Ditjenbun (2008) mempunyai nilai total menthol 75\% dan menthol bebas 53\%.

Pada $M$. arvensis Mear 12, kadar minyak yang relatif tinggisebesar 2,44\% dihasilkan dari perlakuan $69 \mathrm{~kg} \mathrm{~N}+54 \mathrm{~kg}$ $\mathrm{P}_{2} \mathrm{O}_{5}+94,5 \mathrm{~kg} \mathrm{~K} \mathrm{~K}_{2} \mathrm{O}$ diikuti perlakuan $92 \mathrm{~kg}$ $\mathrm{N}+90 \mathrm{~kg} \mathrm{P}_{2} \mathrm{O}_{5}+126 \mathrm{~kg} \mathrm{~K}_{2} \mathrm{O}$ sebesar 2,09 $\%$. Bila diperhitungkan dengan bobot kering terna dan kadar minyak yang diperoleh, maka untuk sekali panen, perlakuan $69 \mathrm{~kg} \mathrm{~N}+54$ $\mathrm{kg} \mathrm{P}_{2} \mathrm{O}_{5}+94,5 \mathrm{~kg} \mathrm{~K}_{2} \mathrm{O}$ dapat menghasilkan \pm $39 \mathrm{~kg}$ minyak, sedangkan perlakuan $92 \mathrm{~kg} \mathrm{~N}$ 
+ $90 \mathrm{~kg} \mathrm{P}_{2} \mathrm{O}_{5}+126 \mathrm{~kg} \mathrm{~K}_{2} \mathrm{O}$ menghasilkan \pm $54 \mathrm{~kg}$ minyak. Pada pertanaman Mentha piperita (berumur 95 hari setelah tanam), aplikasi $90 \mathrm{~kg} \mathrm{P}_{2} \mathrm{O}_{5} / \mathrm{ha}$ menghasilkan kadar minyak mentha (essential oil) sebesar 2,19\%, sedangkan peningkatan pupuk P menjadi 110 - $140 \mathrm{~kg} \mathrm{P}_{2} \mathrm{O}_{5} / \mathrm{ha}$ meningkatkan bobot segar dan kering terna dan menurunkan kadar minyak (Carlos et l. 2004). Kadar menthol total pada semua perlakuan pemupukan lebih besar dari 50\%, yaitu berkisar 51,22 - 61,07 $\%$. Mentha $s p$ merupakan tanaman perenial yang memiliki masa produktif 3 sampai 5 tahun tergantung faktor genetik dan lingkungannya (Alsafar dan Al-Hassan 2009). Fosfor merupakan salah satu unsur yang sangat dibutuhkan dalam biosintesis menthol, karena merupakan penyusun senyawa geranil pirofosfat dan neril pirofosfat yang dalam proses biosintesis selanjutnya akan menghasilkan senyawa menthol pada tanaman mentha.

\section{Produksi minyak dan menthol}

Pemupukan NPK berpengaruh nyata terhadap produksi minyak dan menthol per ha (Gambar 2). Pemupukan $92 \mathrm{~kg} \mathrm{~N}+72 \mathrm{~kg}$ $\mathrm{P}_{2} \mathrm{O}_{5}+126 \mathrm{~kg} \mathrm{~K} \mathrm{~K}_{2} \mathrm{O} / \mathrm{ha}$ menghasilkan produksi minyak dan menthol tertinggi (41 dan $25 \mathrm{~kg} / \mathrm{ha}$ ) pada satu kali panen. Peningkatan kandungan minyak atsiri tanaman yang signifikan dengan meningkatnya kadar nutrisi dikarenakan ketersediaan asimilat yang lebih tinggi untuk mensintesis lebih banyak minyak. Degradasi karbohidrat dan protein akan menghasilkan perkursor dari minyak atsiri (Guenther 1948). Sukrosa sebagai hasil fotosintesis mengalami pemecahan membentuk glukosa, fruktosa, dan UDP-glukosa yang kemudian dikonversi menjadi hexose-phosphate untuk memasuki jalur glikolisis. Produk glikolisis berupa glyceraldehide-3-phosphate

(triosephosphate) dan pyruvate merupakan prekursor biosintesis terpenoid pada tumbuhan, melalui jalur metil erithritol phosphate (MEP) yang merupakan salah satu jalur pembentukan minyak esensial pada tumbuhan (Luthra et al. 1999).

Penggunaan pupuk N, P dan K menunjukkan bahwa pemupukan nitrogen dapat meningkatkan produksi minyak tapi tidak dapat mengubah mutu, sedangkan pupuk Fosfor, Kalium dan kombinasi ketiganya bervariasi pengaruhnya terhadap produksi minyak dan berbeda antar satu penelitian dengan lainnya (Dutta 1971; Baslas 1970, Trisilawati dan Hobir 1991). Walaupun peningkatan dosis pupuk NPK berpengaruh secara signifikan terhadap produksi minyak Mentha, tetapi peningkatan dosis pupuk NPK tidak berpengaruh secara signifikan terhadap mutu minyak atau kandungan mentholnya. Penggunaan 50 sampai $200 \mathrm{~kg}$ N/ha menghasilkan kadar menthol sebesar 78 sampai $82,4 \%$ pada beberapa kultivar $M$. arvensis. Berlawanan dengan kandungan senyawa menthol yang lainnya seperti "neomenthol, menthyl acetat, isomenthone, dan menthone" yang dipengaruhi oleh dosis NPK (Anwar et al. 2010). Munsi (1992) mendapatkan bahwa pemupukan $\mathrm{N}$ dan $\mathrm{P}$ tidak berpengaruh signifikan terhadap kandungan menthol $M$. arvensis. Kandungan menthol $M$. arvensis tanpa pupuk $\mathrm{N}$ sebesar $74,7 \%$ dan pada pemupukan $100 \mathrm{~kg} \mathrm{~N}$ sebesar $75 \%$.

\section{Serapan hara N, P dan K}

Nilai kandungan hara $\mathrm{N}, \mathrm{P}, \mathrm{K}$ bila diperhitungkan dengan bobot kering terna tanaman akan menghasilkan nilai hara yang terserap/terangkut saat panen terna pertama dari dua nomor harapan M. arvensis (Gambar 3). Besarnya hara yang terangkut pada panen terna pertama dari Mear 0010, $\mathrm{N}>\mathrm{K}>\mathrm{P}$, berturut-turut 41-86 kg N, 4-8 kg P dan 2975 $\mathrm{kg} \mathrm{K}$ yang setara dengan $89-187 \mathrm{~kg}$ Urea/ha, 25-50 kg SP-36/ha, dan 55,77-144,23 kg $\mathrm{KCl} / \mathrm{ha}$. Sedangkan hara terangkut dari Mear 
$0012, \mathrm{~N}>\mathrm{K}>\mathrm{P}$, berturut-turut $33-59 \mathrm{~kg} \mathrm{~N}$, $3-6 \mathrm{~kg} \mathrm{P}$ dan $26-48 \mathrm{~kg} \mathrm{~K} / \mathrm{ha}$ yang setara dengan $72-128 \mathrm{~kg}$ Urea/ha, $18,75-37,5 \mathrm{~kg}$ SP-36/ha, dan 50-88,46 kg KCl/ha. Serapan hara NPK tertinggi didapat dari perlakuan pemupukan $92 \mathrm{~kg} \mathrm{~N}+72 \mathrm{~kg} \mathrm{P}_{2} \mathrm{O}_{5}+126 \mathrm{~kg}$
$\mathrm{K}_{2} \mathrm{O} /$ ha. Kalium (K) merupakan unsur kedua terbanyak pada daun Mentha piperita $(2,12 \%)$ dibandingkan $\mathrm{N}(3,72 \%)$. Aplikasi 1,5-3 mmol larutan $\mathrm{K} / \mathrm{L}$ menghasilkan bobot kering bagian atas tanaman terbaik (Valmorbida dan Boaro 2007).

Tabel 2. Kadar minyak, menthol bebas dan menthol total tanaman M. Arvensis

\begin{tabular}{|c|c|c|c|}
\hline Perlakuan & Kadar minyak & Menthol bebas & Menthol total \\
\hline Mear 0010 & \multicolumn{3}{|c|}{$\%$} \\
\hline Kontrol & 2.29 & 27,38 & 56,99 \\
\hline $69 \mathrm{~kg} \mathrm{~N}+54 \mathrm{~kg} \mathrm{P}_{2} \mathrm{O}_{5}+94,5 \mathrm{~kg} \mathrm{~K}_{2} \mathrm{O}$ & 1,53 & 25,73 & 57,03 \\
\hline $69 \mathrm{~kg} \mathrm{~N}+72 \mathrm{~kg} \mathrm{P}_{2} \mathrm{O}_{5}+94,5 \mathrm{~kg} \mathrm{~K}_{2} \mathrm{O}$ & 1,25 & 25,82 & 65,54 \\
\hline $69 \mathrm{~kg} \mathrm{~N}+90 \mathrm{~kg} \mathrm{P}_{2} \mathrm{O}_{5}+94,5 \mathrm{~kg} \mathrm{~K}_{2} \mathrm{O}$ & 2,40 & 27,47 & 58,82 \\
\hline $92 \mathrm{~kg} \mathrm{~N}+90 \mathrm{~kg} \mathrm{P}_{2} \mathrm{O}_{5}+126 \mathrm{~kg} \mathrm{~K}_{2} \mathrm{O}$ & 2,20 & 27,07 & 57,91 \\
\hline $92 \mathrm{~kg} \mathrm{~N}+72 \mathrm{~kg} \mathrm{P}_{2} \mathrm{O}_{5}+126 \mathrm{~kg} \mathrm{~K}_{2} \mathrm{O}$ & 2,10 & 26,59 & 63,98 \\
\hline $138 \mathrm{~kg} \mathrm{~N}+90 \mathrm{~kg} \mathrm{P}_{2} \mathrm{O}_{5}+126 \mathrm{~kg} \mathrm{~K}_{2} \mathrm{O}$ & 2,57 & 26,94 & 59,46 \\
\hline \multicolumn{4}{|l|}{ Mear 0012} \\
\hline Kontrol & 2,13 & 27,06 & 56,46 \\
\hline $69 \mathrm{~kg} \mathrm{~N}+54 \mathrm{~kg} \mathrm{P}_{2} \mathrm{O}_{5}+94,5 \mathrm{~kg} \mathrm{~K}_{2} \mathrm{O}$ & 2,44 & 30,76 & 58,30 \\
\hline $69 \mathrm{~kg} \mathrm{~N}+72 \mathrm{~kg} \mathrm{P}_{2} \mathrm{O}_{5}+94,5 \mathrm{~kg} \mathrm{~K}_{2} \mathrm{O}$ & 1,54 & 28,19 & 61,07 \\
\hline $69 \mathrm{~kg} \mathrm{~N}+90 \mathrm{~kg} \mathrm{P}_{2} \mathrm{O}_{5}+94,5 \mathrm{~kg} \mathrm{~K}_{2} \mathrm{O}$ & 1,08 & 28,39 & 57,60 \\
\hline $92 \mathrm{~kg} \mathrm{~N}+90 \mathrm{~kg} \mathrm{P}_{2} \mathrm{O}_{5}+126 \mathrm{~kg} \mathrm{~K}_{2} \mathrm{O}$ & 2,09 & 30,05 & 55,39 \\
\hline $92 \mathrm{~kg} \mathrm{~N}+72 \mathrm{~kg} \mathrm{P}_{2} \mathrm{O}_{5}+126 \mathrm{~kg} \mathrm{~K}_{2} \mathrm{O}$ & 1,92 & 28,41 & 55,42 \\
\hline $138 \mathrm{~kg} \mathrm{~N}+90 \mathrm{~kg} \mathrm{P}_{2} \mathrm{O}_{5}+126 \mathrm{~kg} \mathrm{~K}_{2} \mathrm{O}$ & 1,90 & 28,89 & 51,22 \\
\hline
\end{tabular}
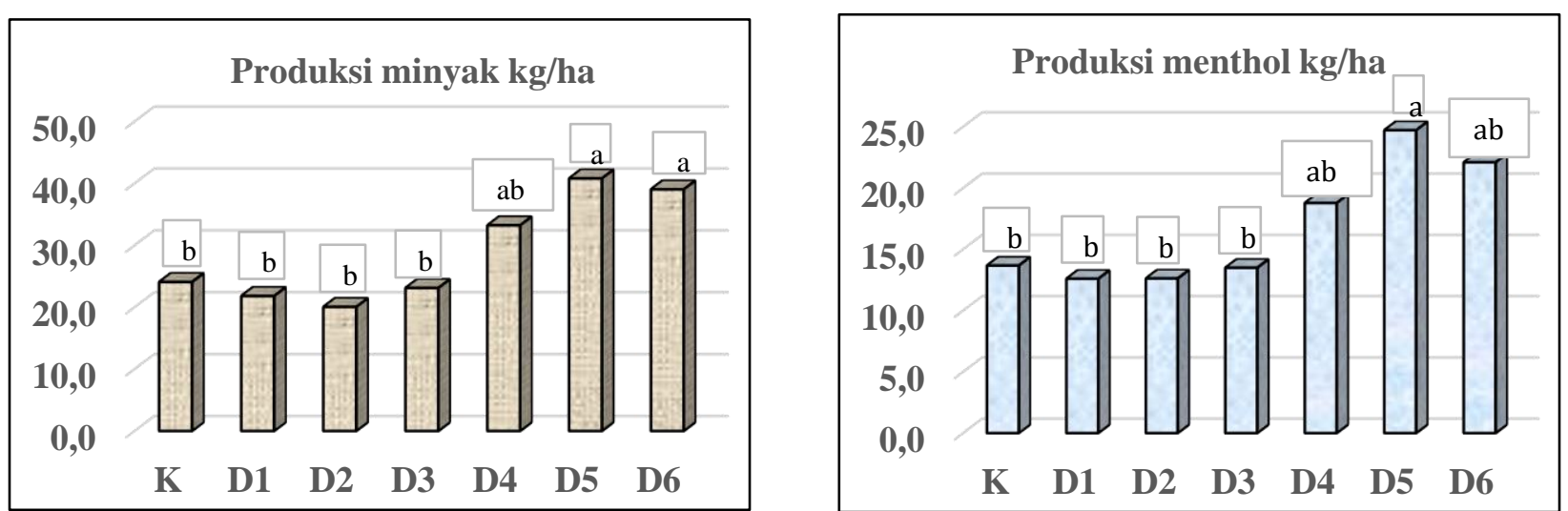

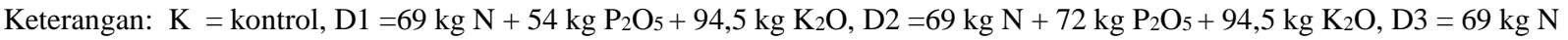

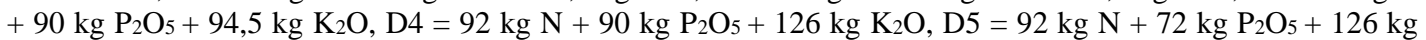

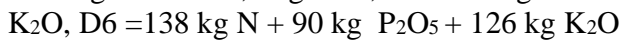

Gambar 2. Produksi minyak dan menthol pada beberapa perlakuan pemupukan 

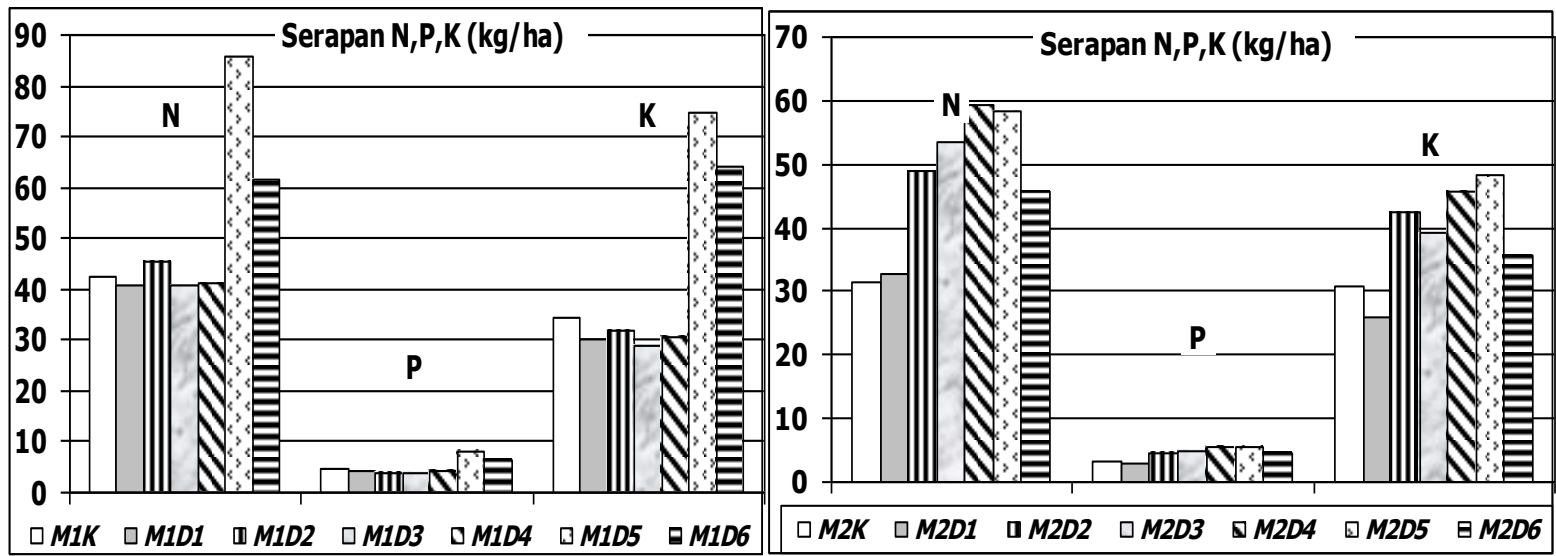

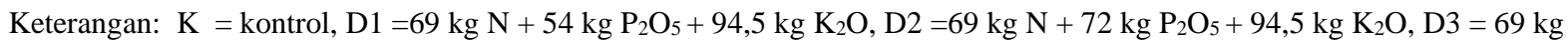

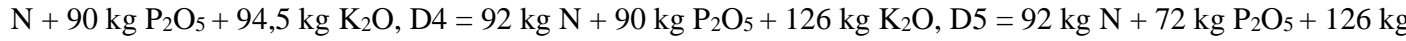
$\mathrm{K}_{2} \mathrm{O}, \mathrm{D} 6=138 \mathrm{~kg} \mathrm{~N}+90 \mathrm{~kg} \mathrm{P}_{2} \mathrm{O}_{5}+126 \mathrm{~kg} \mathrm{~K}_{2} \mathrm{O}$

Gambar 3. Serapan hara N, P dan K per hektar nomor harapan Mear 0010 (kiri) dan Mear 0012 (kanan) pada satu kali panen

Hubungan serapan hara $\mathrm{N}, \mathrm{P}, \mathrm{K}$ terhadap bobot kering terna menunjukkan kadar $\mathrm{N}$ berpengaruh nyata terhadap bobot kering, dan didapat persamaan produksi untuk bobot kering adalah $\mathrm{Ln}(\mathrm{BK})=3,231$ $+0,0082 \ln (\mathrm{N})$, dengan nilai R-sq yang diperoleh sebesar 13,37\%. Hal ini menunjukkan bahwa rataan minyak atsiri akan naik sebesar 1,195 satuan untuk setiap penambahan penyerapan kadar $\mathrm{N}$ satu satuan.

\section{KESIMPULAN}

Penelitian ini menunjukkan bahwa produksi dan mutu mentha hanya dipengaruhi oleh pemupukan NPK

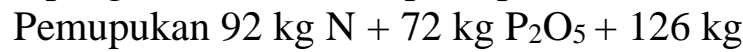
$\mathrm{K}_{2} \mathrm{O} /$ ha pada tanaman $M$. Arvensis untuk kedua no harapan, menghasilkan bobot terna, kadar minyak, kadar menthol total dan hasil minyak mentha yang baik. Pada satu kali panen, produksi minyak dan menthol yang dihasilkan sebesar 41 dan 25 $\mathrm{kg} / \mathrm{há}$.

\section{DAFTAR PUSTAKA}

Alsafar MS, Al-Hassan YM. 2009. Effect of nitrogen and phosphorus fertilizers on growth and oil yield of indigenous mint (Mentha longifolia L.). Biotechnology. 8(3):380-384.

Baslas R. 1970. Studies on the influence of various factors on the essential oil from the plants of mentha piperita. Flavour India. 1:185-187.

BPS. 2005. Statistik Perdagangan Luar Negeri Indonesia. Jilid I. BPS Jakarta. Indonesia.

BPS. 2007. Statistik Industri Besar dan Menengah Tahun 2000 - 2006.

BPS. 2007. Statistik Impor Tahun $2000-$ 2006.

Carlos RR, Faquin V, Trevisan D, Pinto JEB, Bertolucci SKV, Rodrigues TM. (2004. Mineral nutrition, 
growth and essential oil content of mint in nutrient solution under different phosphorous concentration. Horticultura Brasileira. 22 (3):573-578.

Ditjenbun .2008. Pedoman teknis budidaya mentha. direktorat jenderal perkebunan dan balai penelitian tanaman obat dan aromatik. Departemen Pertanian.

Dutta P. 1971. Cultivation of Mentha arvensis in India. The Flavour Industry.

Guenther E. 1948. The Essential Oils. Volume 1. D. Van Nostrand Co. Inc. New York.

Hadipoentyanti E. 1996. Nomor Harapan Mentha yang Potensial untuk Dikembangkan. Warta Puslitbangtri. 2 (2):15-17.

Janice V, Boaro CSF. 2007. Growth and development of mentha piperita 1 . in nutrition solution as affected by rates of potassium. Brazilian Archives of Biology and Technology. 50 (3):379-384.

Luthra R, Luthra PM, Kumar S. 1999. Redefined role of evalonateisoprenoid pathway in terpenoid biosynthesis in higher plants. Current science. 76 (2):133-135.

Mamun BS, Shinta S. 2009. Karakteristik Minyak Atsiri Potensial. Balai Penelitian Tanaman Obat dan Aromatik. Bogor.

Munsi P. 1992. Nitrogen and phosphorus nutrition response in japanese mint cultivation. acta horticulturae. Medicinal and Aromatic Plants. 306: 436-443.

Ozguven, M. and Kirici S. 1999. Research on yield, essential oil, contents and components of mint (mentha spp.) species in different ecologies. Turkish Journal of Agriculture and Forestry. 23(5): 465-472.

Pribadi E. 2010. Peluang Pemenuhan Kebutuhan Produk Mentha spp. di Indonesia. Perspektif. 9 (2): 66-77.

Shormin T, Khan MAH, Alamgir M. 2009. Response of different levels of nitrogen fertilizer and water stress on the growth and yield of japanese mint (Mentha arvensis L.). Bangladesh Journal of Scientific and Industrial Research. 44(1): 137-145.

Tiwari P. 2016. Recent advances and challenges in trichome research and essential oil biosynthesis in mentha arvensis 1. industrial crops and products. Industrial Crops and Products. 82:141-148.

Trisilawati O, Hobir. 1991. Pengaruh pupuk $\mathrm{n}, \mathrm{p}$ dan $\mathrm{k}$ pada produksi terna dan minyak mentha arvensis pada tanah andosol. balai penelitian tanaman rempah dan obat. Pemberitaan Littri. 17(2):43-47.

Trisilawati O. 2012. Pengaruh pemupukan $\mathrm{N}$ dan $\mathrm{P}$ terhadap dua nomor harapan Mentha arvensis. Prosiding Konverensi Nasional Minyak Atsiri.22-29. 
Pengaruh Pemupukan N, P dan K terhadap Produktivitas dan Mutu Minyak M. arvensis 